\section{La farsa de la homeopatía}

\section{The farce of homeopathy}

\section{Sr. Editor:}

La homeopatía es una medicina alternativa ampliamente discutida, considerada por la comunidad científica como una pseudociencia y se asienta en dos principios propuestos, en 1810, por el médico alemán Samuel Hahnemann (17551843), en su Organon de medicina: la "ley de los similares" y la "ley de los infinitesimales". Según la primera, una sustancia que causa ciertos síntomas en un individuo sano curará al paciente enfermo con los mismos síntomas. Según la segunda -una especie de "menos es más"- un remedio se vuelve más efectivo al diluirse, de modo que los más potentes son aquellos diluidos al punto de no contener una sola molécula de la sustancia activa ${ }^{1,2}$.

Según Mario Bunge, la medicina complementaria o alternativa, o no convencional, es una amplia panoplia de terapias sin base ni comprobación científica. Casi siempre son ejercidas por individuos sin preparación médica o por médicos que ocultan sus diplomas universitarios para poder ejercer como chamanes. En los Estados Unidos de Norteamérica, casi la mitad de la población recurre a la medicina "no convencional», en particular quiropráctica, homeopatía, acupuntura y herbalismo, pese a las advertencias del Consumer Report, que la gente consulta y acata antes de comprar automóviles y electrodomésticos ${ }^{3}$.

Las excusas de la homeopatía son, por un lado, la analogía de la ley de los similares con el funcionamiento de las vacunas $y$, por otro, un atisbo de asidero de la doctrina de los infinitesimales, ya que las drogas suelen ser menos efectivas e incluso en dosis perjudiciales en grandes dosis. "El error homeopático -señala Martin Gardner en su clásico Fraudes y falacias en nombre de la ciencia- fue tomar estas verdades parciales, extrapoladas al límite del absurdo y aplicarlas universalmente a todos los medicamentos" 3,4 .

Los ejemplos de la falacia de la homeopatía se ven por doquier. Alberto Rojo, un físico argentino, lo asemeja al aliento del Cesar y responde una vieja pregunta: ¿Cuál es la probabilidad de que, en la bocanada de aire que ustedes acaban de inhalar, haya al menos una molécula de aire de las que exhaló el Cesar? Y la respuesta es un sorprendente 99\% dado que si bien una sola molécula representa una ínfima fracción del aliento, resulta ser casi igual a la fracción del volumen total de la atmósfera ocupada por el aliento ${ }^{4}$. Como dice Bunge, los existencialistas creen que todo es nada; los homeópatas que nada es todo. Existen otras razones sobre la improbabilidad de su funcionamiento, como que en los preparados homeopáticos casi no existe principio activo ${ }^{5}$. En la mayoría de los casos, las diluciones empleadas son cercanas a una dilución al infinito. Un simple cálculo, empleando las masas moleculares y el número de Avogadro, muestra que la mayoría de los preparados homeopáticos son simplemente agua. El principio de "lo similar cura lo similar" no tiene base alguna, ni se explica de ninguna manera cómo lo hace. No hay ningún estudio estadístico publicado que muestre el efecto de un medicamento homeopático comparado con uno de la llamada medicina tradicional. No hay relación causa-efecto entre las supuestas mejorías producidas por un tratamiento homeopático. Los homeópatas comenten la falacia post hoc propter hoc (después de eso, por tanto, a causa de eso). Hay personas que mejoran, pero no hay estudios que muestren estadísticas acerca de qué mejorías se deben a remisiones espontáneas debido a la medicatrix naturae (fuerza medicinal de la naturaleza o retorno espontáneo a la salud) o al efecto placebo.

El abanico de razones por qué la homeopatía es popular incluyen el desencanto del público con la medicina tradicional (despersonalización, poco tiempo, tecnolatría, etc.), el hecho de que ciertas enfermedades aún no tienen cura, el miedo a los efectos secundarios de las drogas convencionales y la comprensión errónea (enraizada en las creencias supersticiosas) de la diferencia entre correlación y causa y efecto.

Las terapias alternativas constituyen la medicina de los ignorantes del método científico, es la de los desahuciados por la medicina "oficial", que aún no ha encontrado tratamientos eficaces para sus males. El relativismo cultural, que suele predicarse en nombre de la tolerancia, niega la posibilidad de la verdad objetiva y universal, de modo que sostiene que las diferencias entre el chamanismo y la medicina científica son culturales o ideológicas. Muchos desconfían de la industria farmacéutica porque vive del dolor ajeno y porque ha cometido algunos errores y delitos imperdonables (venta de cocaína, heroína, talidomida, entre otros). Pero esta justa condena no le permite a los escépticos 
comprar aspirina o antibióticos. Las revistas y editoriales sensacionalistas han sabido vender todo lo alternativo a la racionalidad y la contrastación experimental.

Los científicos y los filósofos tienden a tratar la superstición, la pseudociencia y hasta la anticiencia como algo inofensivo o, incluso, como adecuado al consumo de las masas; están demasiado ocupados con sus propias investigaciones como para molestarse por tales sinsentidos. Esta actitud, sin embargo, es desafortunada. Y ello por las siguientes razones: Primera, la superstición, la pseudociencia y la anticiencia no son basura que pueda ser reciclada con el fin de transformarla en algo útil: se trata de virus intelectuales que pueden atacar a cualquiera -lego o científico- hasta el extremo de hacer enfermar toda una cultura y volverla contra la investigación científica. Los pacientes tratados con este tipo de medicina llegan tarde a la medicina tradicional, a veces cuando el proceso no tiene vuelta atrás. Segunda, el surgimiento y la difusión de la superstición, la pseudociencia y la anticiencia son fenómenos psicosociales importantes, dignos de ser investigados de forma científica $y$, tal vez, hasta de ser utilizados como indicadores del estado de salud de una cultura. Las seudociencias son más populares que las ciencias porque la credulidad está más difundida que el espíritu crítico, el que no se adquiere recopilando y memorizando informaciones, sino repensando lo aprendido y sometiéndolo a prueba. Es deber de los organismos de salud pública proteger a la población de estas prácticas, empezando por despojar de la acreditación a las universidades que las enseñan.

Los efectos de la homeopatía son más cercanos a la sugestión que a la acción química de un compuesto, y a la ilusión que a la dilución.

\section{Pablo Young \\ Servicio de Clínica Médica, Hospital Británico de Buenos Aires, Argentina.}

\section{Referencias}

1. Ballard R. Homeopathy. An overview. Aust Fam Physician 2000; 29: 1145-8.

2. Freckelton I. Death by homeopathy: issues for civil, criminal and coronial law and for health service policy. J Law Med 2012; 19: 454-78.

3. Bunge M. Medicinas tradicionales. En: Mario Bunge, Editores. Filosofía para médicos. Buenos Aires, Argentina: Editorial Gedisa; 1 Ed; 2012. p. 19-40.

4. Rojo A. Lo riguroso y lo intuitivo. En: Alberto Rojo, Editores. El azar en la vida cotidiana. Buenos Aires, Argentina: Editorial Siglo veintiuno; $1^{\circ}$ Ed; 2012. p. 73-91.

5. Giles J. Degrees in homeopathy slated as unscientific. Nature 2007; 446: 352-3.



